\title{
The Al-Invest Contribution to the Resilience of the Chemical Company: Development Cooperation
}

\author{
Tania Elena González Alvarado \\ Universidad de Guadalajara, Mexico Periférico Norte $N^{\circ} 799$, \\ Núcleo Universitario Los Belenes, C.P. 45100, \\ Zapopan, Jalisco, México
}

DOI: https://doi.org/10.36941/jicd-2021-0009

\begin{abstract}
This article aims to identify the contribution of the Al-Invest program to resilience and economic growth in companies in the chemical sector. The study sample consists of 596 European and Latin American companies that benefited from Al-Invest. It was found that Knowledge Transfer was not the main interest in the collaborations. The economic dynamics of the chemical industry pressure companies to compete, having a low impact on local development when it comes to knowledge transfer. Al-Invests contribution is oriented to the company in four aspects: relational capital with foreign agents, geographic openness, open innovation, and greater technological and marketing capacity. These four elements increase the resilience and economic growth of the company, accompanied by a favorable impact on economic development in the region.
\end{abstract}

Keywords: International cooperation; economic development; investigation and development; SMEs; competitiveness

\section{Introduction}

Analyzing the links between companies in the chemical industry in programs such as Al Invest ${ }^{1}$-development cooperation- contributes to the construction of new paths to

\footnotetext{
${ }^{1}$ The AL-INVEST Program is one of the most important of the European Commission in Latin America. It emerged in 1994 to attract European investment to Latin America. It changed to promote the internationalization of micro, small, and medium-sized companies in Latin America. The program pursues the development of Latin American regions through the insertion of companies into international networks.
} 
development. With this, international cooperation programs can be adjusted to contribute to economic growth; increase resilience, and generate effective responses to the industry to the restrictions derived from mitigating mechanisms for climate change.

Additionally, understanding the dynamics of companies in the framework of development cooperation contributes to the creation and adoption of new business models that, in turn, generate sustained growth. All of this applies to the chemical industry. It is an industry that adapted to the changes of the last year with less impact compared to other industries. (Deloitte, 2021)

The flexibility to adapt is due to the combination of various articulating mechanisms. These mechanisms are partnerships, cooperation, tolling arrangements, or more broadly designed research programs -as well as the design of smaller, moreflexible production units, since they have been already adopted by other industries, such as pharma companies (Hilton, 2021). For example, chemical companies in the United States have responded to the crisis by focusing on operational efficiency, asset optimization, and cost management to succeed in this shifting industry landscape, chemical companies should consider implementing a series of targeted, strategic initiatives across major functional areas such as R\&D and technology (Deloitte, 2021).

Now, the industry faces a possible decrease in the demand for chemical products due to deglobalization and regulations to face climate change (Hilton, 2021).

The article aims to identify the contribution of the Al-Invest program to resilience and economic growth in companies in the chemical sector. This document is divided into three parts, the first one deals with the theory of cooperative links, company networks, and their importance for business resilience. The methodology is described in the second section. The third presents the discussion of the results of the Al-Invest program, with support from the situation of the chemical sector and its importance for other industries, as well as the triangulation with other research results.

\section{Theoretical Framework}

The internationalization of the company and its contribution to local development has been studied intensively in recent decades (Rozo, 1993; Stumpo, Katz \& Alarcón, 1996; Rojo, 2001; Kosacoff, 2009; Perrotta, Fulquet \& Inchauspe, 2011; Felzensztein, Deans \& Dana, 2019).

Prebisch (1986) indicated that you cannot have economic growth based only on exporting companies. The local development that accompanies economic growth depends on how, not on internationalization itself.

It is important to note that technology transfer in the chemical industry does not agree with the theoretical explanation. Technology transfer in this industry has more barriers rather than facilities to impact in low-income countries. A possible explanation is that research and development (R\&D) requires large long-term investments, investments that are only supported by intellectual property and industrial secrets. 
Local development based on technology transfer is complicated for many industries. The challenge is even greater. If one considers that large companies correspond to other regions of the world; their commitment to the destination location is usually low. In this case, the transfer would only take place within the specific framework of a program for international cooperation. Even in this last circumstance, since they are global companies collaborating with smaller local companies, the asymmetries would present limitations to the transfer. If the results are not transformed into a common good, then the R\&D projects are not sustainable.

The chemical industry is made up of large corporations that interact with small and specialized industries. Europe, the United States, China, and Japan concentrate more than three-quarters of the market; and receive the main investment flows (Duran-García \& Durán-Aponte, 2011). This scenario shows that smaller companies focused on local consumption - but linked to exporting or transnational companies - contribute to economic development.

In this way, indirect internationalization has a positive impact on the Welfare State. For this reason, studying business linkages is important to understanding local development (Evans, 1979; Butler \& Hansen, 1991; Zcan, 1995; Pietrobelli \& Sverrison, 2005; Helmsing, 1999; Schmitz, 1999; Sternberg, 2000; Trigilia, 2001; Kantis, Ishida \& Komori, 2002; Sverrison, 2005; Alburquerque, 2006; Abramovay, Magalhães \& Schröder, 2008). Foreign Direct Investment (FDI) is also important in sectors with Research and Development (R\&D), (Patel \& Pavitt, 1991; Florida, 1997; Kuemmerle, 1999; Frost, 2001; Kumar, 2001; Chung \& Alcácer, 2002; Le Bas \& Sierra, 2002; Von Zedtwitz \& Gassmann, 2002; Cantwell \& Mudambi, 2005).

The relationship between $\mathrm{FDI}$ and regional development has received more attention than other factors (Ozawa, 1992; Borensztein, De Gregorio \& Lee, 1998; Moran \& Moran, 2000; Mortimore, Vergara \& Katz, 2001; Moran, Graham \& Blomström, 2005; Wei \& Leung, 2005). But it has been shown that FDI alone does not guarantee development (Aitken \& Harrison,1999; Alburquerque, 2001; Lall \& Narula, 2004; Corrales, 2006; Elías, Fernández \& Ferrari, 2006; Jimenez \& Rendon, 2012; Gil, López \& Espinosa, 2014; Rogerson, 2019).

An important factor is a way in which economic agents are articulated. For this reason, the study of international business cooperation networks arises (Eriksson \& Johanson, 1996; Holm, Eriksson \& Johanson, 1996; Fritsch \& Lukas, 2001; Contractor \& Lorange, 2002; Haahti et al., 2005; Holm, Wright, Westhead \& Ucbasaran, 2007).

According to Pérez (2012), there are three types of channels for the dissemination of technology and/or knowledge: informal, formal, and commercial. The informal channel includes established personal interactions without formal organizational relationships. (Dahl \& Pedersen, 2002; Pérez, 2012).

The formal channel refers to the transmission of knowledge (i) encoded by formal means, such as publications, technical reports, and conferences; and (ii) tacit, via human capital, such as formal organizational agreements for staff mobility and workforce 
training. (Arvanitis, Kubli \& Wörter, 2005; Pérez, 2012).

The commercialization channel is based on scientific activities with a commercial orientation on specific processes or products: science-based companies, research contracts, consultancy, patents, and licenses. (Perkmann \& Walsh, 2007; Pérez, 2012).

Knowledge transfer is easier when it comes to cooperation (creating value to share) between companies. Cooperation leads to the creation, integration, transfer, and absorption of knowledge. Knowledge is created in long-term cooperation (conflict and tension) and integrated. Sometimes it's scattered and disjointed, but the conflict and tension create channels of communication. Thus, a permanent negotiation process is built that gives logical order to the collective knowledge for its application.

The longer a network of companies has, the greater the transfer of knowledge because the appropriate channels exist, and the collective absorption of knowledge is favored. This theoretically explains the international networks in the Chemical Industry.

Enterprise networks are based on adaptive systems. The properties of the adaptive system are 1) aggregation, as companies contribute to the Gross Domestic Product; 2) flows, feedback from production, and the multiplier effect; 3) non-linearity, as there are catalysts; and 4) the diversity (Holland, 1992). The properties allow flexibility to adapt to changes. Adaptation sometimes leads to better circumstances than the previous ones, even though the scenario is highly negative and unstable. In other words, the relationships that companies establish contribute to resilience and economic growth.

\section{Methodology}

The original data were provided by the Nafin Euro center (Nacional Financiera, Spanish name). Al-Invest's chemical industry database includes 596 participating companies from 2002 to 2009. Actually, the companies have a website, collaborate with foreign companies, and appear in various electronic directories. After eleven years, the data of the Web-based companies was updated without the need to interact with the entrepreneurs. The companies continue their international activities.

Krippendorff (2018) defines content analysis as a research technique for making replicable and valid inferences from data to their context. Qualitative content analysis is like textual analysis in that it is primarily interpretive in nature and does not utilize statistics for data analysis (Kim \& Kuljis, 2010). This method requires analysing each company as a case study. This makes the research work more laborious, but the information is obtained that statistics sometimes do not offer (Flyvbjerg, 2006).

\section{Discussion of Results}

The chemical industry grew rapidly from the end of the 19th century to the present day, based mainly on oil and its derivatives. Most of the growth has occurred in the Asian region. In the last years of the 20th century, complementary industries were developed, 
such as polymers, semiconductor materials, pharmaceuticals, and agrochemicals. Nanotechnology has contributed in recent years to the transformation of the chemical industry. (Montes-Valencia, 2015).

The strategies of transnational companies are complex, due to the diversity that characterizes them, as well as the different economic scenarios to which they adapt (Deloitte, 2016).

Chemical industry transnationals had a difficult operating environment in 2015. The decline in global commodity prices put demand pressure on chemical companies serving these final marketplaces and created a more challenging environment for biochemical companies competing with petroleum-based substitutes (Deloitte, 2016).

Global chemical companies with stable balance sheets and continuous cash flows sought acquisitions in 2015 to achieve growth (Deloitte, 2016). Business cooperation is encouraged in crisis time. The acquisition becomes survival and growth strategies ${ }^{2}$.

Graph 1 shows the sales volume of the most important companies worldwide. If the origin of the transnationals is considered, instead of the regions in which they operate, then Asia abandons its prominent place, and the transnationals of German and American origin are shown as the main parts of the world scene.

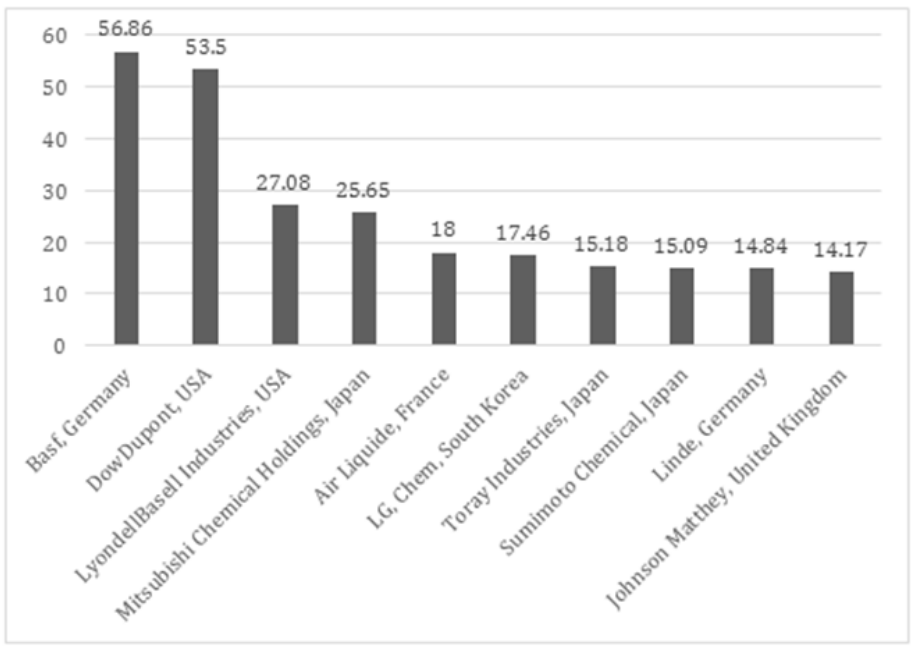

Graph 1: Chemical Companies ranking in 2018 (Billions of Dollars)

Source: Sevilla (2019)

Germany accounts for five percent of world turnover. It is the fourth largest chemicalproducing country, with China, the United States, and Japan being the first. The German

\footnotetext{
${ }^{2}$ In November 2015, Air Liquide announced the $\$ 13.4$ billion acquisition of Airgas, bringing together two complementary businesses to provide greater value, service, and innovation to its customers. (Deloitte, 2016) 
chemical-pharmaceutical industry is highly exporting, and its export share has increased considerably in recent years. (Bilbao, 2015)

German transnationals employ more than 50,000 people. Companies with more than 1,000 workers, which represent $3 \%$ of the total number of companies, invoice $46 \%$ of the sector. The German chemical industry includes 1,931 companies employing 444,800 people. In this group, there is a greater number of small and medium-sized companies (Bilbao, 2015).

Germany has strategically combined local and international networks. It has chemical parks, extensive industrial areas in which companies that produce the chemical sector are located, and which are complemented by a complex transport network, which makes its operation more efficient. It is also a pole of Know-How and innovation (Bilbao, 2015).

International networks prolong local development, as the catalytic companies of the local network become increasingly global. In this way, expansion to other markets has a positive impact on the locality of origin. The transfer of knowledge derived from $R \& D$ favors geographically close companies, within the local network of the country of origin.

A competitive disadvantage for the German chemical industry is it dependence on fossil fuel imports. This has led to direct investments to other more profitable sectors, to relocate production (Bilbao, 2015). According to development cooperation, Al-Invest participating companies from the chemical industry should focus on knowledge transfer. Mainly because in this industry, the transfer is key for local economic development linked to international networks.

However, the international business cooperation network is not exempt from the pressure to increase profitability, therefore, between one region and another, companies differ in the way they are articulated with "the local".

Transnational companies protect knowledge and create barriers to knowledge transfer in regions that are attractive for cost reduction. This knowledge is related to research and development (R\&D) and is key to international competitiveness.

The German Chemical Industry has strengthened the local network in Germany and articulated its activities to international networks. This combination of local and international creates international competitive advantages because it provides intangible resources that are not very imitable that guarantee the economic sustainability of the business.

The Mexican and Argentine companies in Al-Invest are numerous compared to those of other participating countries (Tables 1 and 2). This may be because there are more young and smaller companies in the Latin American region than in Europe. Europe is a leading R\&D region. Europe is the region that provides knowledge and Latin America is the recipient. Unfortunately, Latin America is a consumer of products and services offered by European industry rather than a recipient of knowledge. The reality for Latin America seems far from the Spanish one. Raposo (2004) identified that leading R\&D 
companies support the innovation of Spanish companies.

Table 1: European companies by event for the Chemical Industry

\begin{tabular}{lccccc} 
Year & 2002 & 2003 & 2005 & 2006 & Total \\
Germany & 11 & 24 & 19 & 15 & 69 \\
Spain & 10 & 16 & 14 & 17 & 57 \\
France & 7 & 18 & 10 & 12 & 47 \\
Finland & 1 & 8 & 0 & 0 & 9 \\
England & 3 & 6 & 1 & 0 & 10 \\
Italy & 14 & 19 & 16 & 12 & 61 \\
Sweden & 9 & 0 & 1 & 0 & 10 \\
Switzerland & 0 & 4 & 0 & 0 & 4 \\
Austria & 0 & 0 & 1 & 0 & 1 \\
Netherlands & 0 & 0 & 1 & 0 & 1 \\
Total & 55 & 95 & 63 & 56 & 269 \\
\hline
\end{tabular}

Source: Own elaboration.

Table 2: Latin American companies by event for the Chemical Industry

\begin{tabular}{llllll}
\hline Year & $\mathbf{2 0 0 2}$ & $\mathbf{2 0 0 3}$ & $\mathbf{2 0 0 5}$ & $\mathbf{2 0 0 6}$ & Total \\
\hline Argentina & 4 & 11 & 15 & 8 & 38 \\
\hline Guatemala & 1 & 0 & 0 & 0 & 1 \\
\hline Mexico & 98 & 19 & 149 & 10 & 276 \\
\hline Chile & 0 & 3 & 0 & 4 & 7 \\
\hline Colombia & 0 & 1 & 0 & 2 & 3 \\
\hline Venezuela & 0 & 1 & 0 & 0 & 1 \\
\hline Brazil & 0 & 0 & 0 & 1 & 1 \\
\hline Total & 103 & 35 & 164 & 25 & 327 \\
\hline
\end{tabular}

Source: Own elaboration

Global companies have business units in destination countries. In this way, they maintain a relatively small size, and with this, they combine the advantages granted by their global operation with the flexibility that being a small company provides.

By combining the sizes and using the transfer media (informal channel, formal channel, and marketing), the market-leading company gains greater control over the transfer and its benefits. This possibly explains the results presented in table 3 . This shows that, in Al-Invest, companies favor representation agreements (41.44) compared to knowledge transfer (10.07\%). 
Table 3: Type of cooperation in Al-Invest

$\begin{array}{lcc}\text { Type } & \text { Frequency } & \% \\ \text { Knowledge transfer } & 60 & 10.07 \\ \text { Business consulting } & 5 & 0.84 \\ \text { Joint Venture } & 21 & 3.52 \\ \text { Outsourcing } & 36 & 6.04 \\ \text { Franchise } & 11 & 1.85 \\ \text { Alliance } & 33 & 5.54 \\ \text { Association } & 17 & 2.85 \\ \text { License } & 16 & 2.68 \\ \text { Financial co-investment } & 22 & 3.69 \\ \text { Investors } & 13 & 2.18 \\ \text { Concessions } & 1 & 0.17 \\ \text { Commercialization } & 71 & 11.91 \\ \text { Import } & 12 & 2.01 \\ \text { Distribution } & 169 & 28.36 \\ \text { Product search } & 219 & 36.74 \\ \text { Product offer } & 132 & 22.15 \\ \text { Turnkey project } & 18 & 3.02 \\ \text { Representation agreements } & 247 & 41.44 \\ \text { Equipment } & 26 & 4.36\end{array}$

Source: Own elaboration

The most frequent barriers to transfer in the chemical industry are technical ignorance when selecting, negotiating, and acquiring a technology; absence of a previous systemic study for the selection and acquisition of technology; the obligation to keep the knowledge transferred secret, beyond the term of the technology commercialization contract; legal aspects on the part of the country where the industry that transfers the technology is located (Durán-García \& Durán-Aponte, 2011). Knowledge transfer in the chemical industry requires strong and long-term links, due to the complexity of the transfer and the possibility of acts of opportunism. Attending a business meeting to find partners to enter a market easily translates into asymmetric relationships

Innovation in these companies follows a different pattern than technology transfer. Table 3 shows the following: representation agreements, product search, and distribution. Thus, innovation develops in other dimensions, both within the company and among the members of the network. This is consistent with the results achieved in other projects in the last year. The triangulation between the results of this project and those of third parties offers a proposal that contributes to the business resilience and economic growth of the company.

The capabilities in the use of technologies and marketing development have dominant and positive effects on the performance of the company in international markets. (Davcik et al., 2021) In addition, the dynamics of Al-invest offer the company inclusion in groups. Membership of an international group influences the geographic 
openness of SME innovation (Deltour, Le Gall \& Lethiais, 2021). Innovation capacity and competitive advantage also significantly influence business performance (Mulyana \& Wasitowati, 2021).

Ryu, Baek \& Yoon (2021) consider that SMEs cooperate with external partners to strengthen their technological innovation capabilities and thus improve their international performance. From the perspective of open innovation, these scholars explore the effects of relational capital and technological innovation capacity on international performance, with a particular focus on the moderating effect of linkage proactivity. They were based on 175 SMEs. The analysis showed that, first, relational capital had a significant effect on the capacity for technological innovation. Second, the capacity for technological innovation has a significant influence on international performance. Third, the capacity for technological innovation catalyzed the relationship between relational capital and international performance. Finally, they found that the proactivity of the link moderates the relationship between technological innovation capacity and international performance. The key findings of their research imply that relational capital and the proactivity of alliances are the key drivers of international performance. (Ryu, Baek \& Yoon, 2021).

Jee and Sohn (2021) used a Heckman selection model to analyze 1,020 Korean SMEs engaged in product innovation. They found that formal intellectual property rights have a lower contribution to appropriation than the expected level. Instead, they found some positive links between SMEs' affirmative perception of informal means of IP protection, especially complex design, and its appropriation in both complex and discrete sectors. They analyzed the management of intellectual property and the policy implications to improve the value appropriation of SMEs (Jee \& Sohn, 2021).

Considering the results on Al-Invest, the current context of the chemical industry, and the results of third investigations, it is considered that the Al-Invest program contributes to the resilience and economic growth of the company in four aspects: (1) Relational capital with international partners; (2) geographic opening with an incursion in foreign markets; (3) Open innovation and collective intelligence; (4) high technological and marketing capacity (Figure 1).

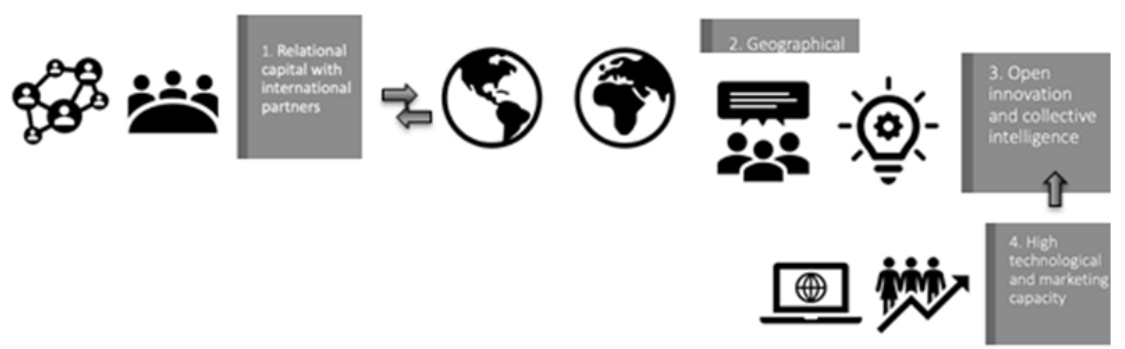

Figure 1: Contribution of the Al-Invest program to the resilience and economic growth of the chemical sector company

Source: Own elaboration 
1. Relational capital: greater diversification in collaborations, greater multiculturalism, and social inclusion. All this contributes to the best adaptation to unexpected changes

2. Geographical opening: better use of the territory combined with social inclusion, better and more jobs.

3. Open innovation and collective intelligence: builds learning communities with the appropriation of knowledge and collaboration for new forms and lifestyles that respond to climate change and economic crises.

4. High technological and marketing capacity: the result of the resilience and growth of the company, which, in turn, maximizes the use of relational capital, geographic openness, and open innovation.

These four contributions support the following research proposal: the direct benefit for the target regions in terms of local development may be employed. It is important to analyze the quality of these jobs. Graph 2 shows the creation of jobs in the chemical industry worldwide. In this graph, the Asian region takes a prominent position compared to other regions and countries.

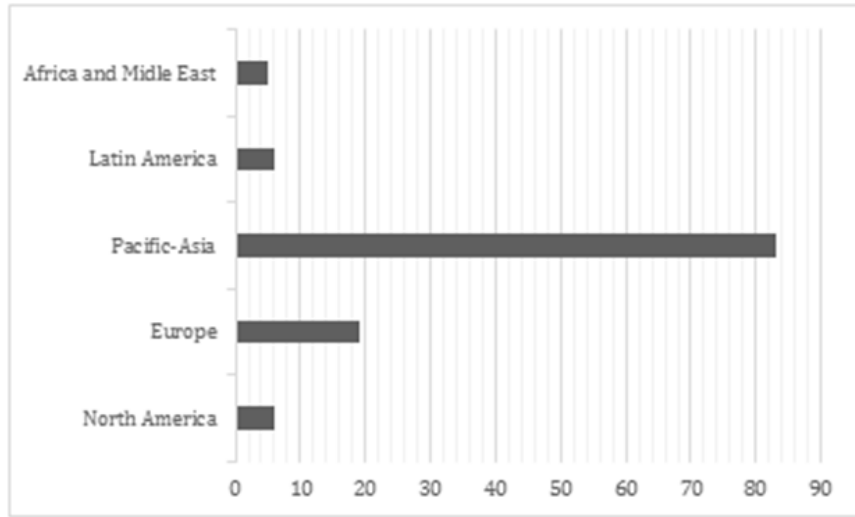

Graph 2: Contribution to jobs in the chemical industry by region (in millions) Source: ICCA (2018)

\section{Conclusion}

The dynamics of the chemical industry press for companies to compete rather than cooperate. The analysis shows that Knowledge Transfer is not the main objective. This does not depend on multilateral organizations or governments. Even with this scenario, the international business cooperation networks invested in the resilience of the companies. While it is true that these networks are created within the framework of development cooperation, it is also true that they are characterized by the centerperiphery logic. 
Al-Invest provide benefits to companies: resilience and economic growth. In addition to job creation. New lines of research are proposed: analysis of the quality of the jobs created; description of the relationship between resilience and growth in companies during the pandemic; analysis of the adoption and development of collective intelligence.

\section{References}

Abramovay, R., Magalhães, R., \& Schröder, M. (2008), "Social movements beyond the iron cage: Weak ties in territorial development", World Development, 36(12), 2906-2920.

Aitken, J., \& Harrison, A. (1999), "Do domestic firms benefit from direct foreign investment? Evidence from Venezuela", American Economic Review, 605-618.

Alburquerque, F. (2006), Clusters, territorio y desarrollo empresarial: diferentes modelos de organización productiva, in Cuarto taller de la Red de Proyectos de Integración productiva, BID/FOMIN, San José; Costa Rica.

Alburquerque, F. (2001), Desarrollo económico local y cooperación descentralizada para el desarrollo, Desarrollar lo local para una globalización alternativa. HEGOA, Euskal Fondoa. San Sebastián; Spain.

Arvanitis, S., Kubli, U., \& Wörter, M. (2005), "Determinants of knowledge and technology transfer activities between firms and science institutions in Switzerland: An analysis based on firm data", Swiss Institute for Business Cycle Research Working Papers, $\mathrm{N}^{\circ} 116$.

Bilbao, M. (2015), La industria química en Alemania: una visión general. Oficina Económica y Comercial de España, Germany.

Borensztein, E., De Gregorio, J., \& Lee, J. (1998), "How does foreign direct investment affect economic growth?”, Journal of International Economics, 45(1), 115-135.

Butler, J., \& Hansen, G. (1991), “Network evolution, entrepreneurial success, and regional development, Entrepreneurship \& Regional Development", 3(1), 1-16.

Cantwell, J., \& Mudambi, R. (2005), “MNE competence-creating subsidiary mandates”, Strategic Management Journal, 26(12), 1109-1128.

Chung, W., \& Alcácer, J. (2002), "Knowledge seeking and location choice of foreign direct investment in the United States", Management Science, 48(1), 1534-1554.

Contractor, J., \& Lorange, P. (ed.) (2002), Cooperative strategies and alliances in international business. Pergamon.

Corrales, C. (2006), "La inversión extranjera como determinante del desarrollo en América Latina", Revista Ciencias Estratégicas, 14(15), 21-32.

Dahl, M., \& Pedersen, C. (2004), “Knowledge flows through informal contacts in industrial clusters: myth or reality?", Research Policy, 33(10), 1673-1686.

Davcik, N. S., Cardinali, S., Sharma, P., \& Cedrola, E. (2021), Exploring the role of international R\&D activities in the impact of technological and marketing capabilities on SMEs' performance", Journal of Business Research, 128, 650-660.

Deloitte. (2016), Panorama de fusiones y adquisiciones en la Industria Química global, 2016. Deloitte, Mexico.

Deloitte (2021), Chemical industry outlook, Deloitte, Mexico.

Deltour, F., Le Gall, S., \& Lethiais, V. (2021), “Partners and Geographical Scale of SMEs' Open Innovation: does Business Group Affiliation Matter?", International Journal of Innovation Management, 2150064.

Durán-García, M., \& Durán-Aponte, E. (2011), “Criterios organizacionales y de gestión en la transferencia de la tecnología química”, Economía Gestión y Desarrollo, (12), 25-38.

Elías, S., Fernández, M., \& Ferrari, A. (2006), Inversión extranjera directa y crecimiento económico: un análisis empírico, Departamento de Economía, Universidad Nacional del Sur.

Evans, B. (1979), Dependent development: The alliance of multinational, state, and local capital in Brazil. Princeton University Press.

Felzensztein, C., Deans, K. R., \& Dana, L. P. (2019), "Small firms in regional clusters: local networks and internationalization in the Southern Hemisphere", Journal of Small Business Management, 57(2), 496-516.

Florida, R. (1997), "The globalization of R\&D: Results of a survey of foreign-affiliated R\&D laboratories in the USA", Research Policy, 26(1), 85-103.

Flyvbjerg, B. (2006), "Five misunderstandings about case-study research", Qualitative Inquiry, 12(2), 219-245.

Fritsch, M., \& Lukas, R. (2001), “Who cooperates on R\&D?”, Research Policy, 30 (2), 297-312.

Frost, T. (2001), "The geographic sources of foreign subsidiaries' innovations", Strategic Management Journal, 22(2), 101123. 
GIL, E., López, S., \& Espinosa, D. (2014), "Factores determinantes de la inversión extranjera directa en América del Sur", Perfil de Coyuntura Económica, 22, 55-85.

Haahti, A., Madupu, V., Yavas, U., \& Babakus, E. (2005), “Cooperative strategy, knowledge intensity and export performance of small and medium sized enterprises", Journal of World Business, 40(2), 124-138.

Helmsing, A. (1999), "Teorías de desarrollo industrial regional y políticas de segunda y tercera generación", EURE (Santiago), 25(75) 5-39.

Hilton, S. (2021), The three biggest influences on the chemical industry in 2021. The chemical industry. AG Chemi Gropu Blog. Link: https://blog.agchemigroup.eu/the-three-biggest-influences-on-the-chemical-industry-in-2021/

Holm, D., Eriksson, K., \& Johanson, J. (1996), "Business networks and cooperation in international business relationships", Journal of International Business Studies, 27(5) 1033-1053.

ICCA, (2018), The Global Chemical Industry: Catalyzing Growth and Addressing Our World's Sustainability Challenges, International Council of Chemical Associations, Washington; USA.

Jee, S. J., \& Sohn, S. Y. (2021), "Perceived importance of intellectual property protection methods by Korean SMEs involved in product innovation and their value appropriation", Journal of Small Business Management, 1-27.

Jimenez, D., \& Rendon, H. (2012), "Determinantes y efectos de la Inversión Extranjera Directa: revisión de literatura", Ensayos de Economía, 22(41) 109-128.

Kantis, H, Ishida, M., \& Komori, M. (2002), Empresarialidad en economías emergentes: Creación y desarrollo de nuevas empresas en América Latina y el Este de Asia, Inter-American Development Bank.

Kim, I., \& Kuljis, J. (2010), "Applying content analysis to web-based content", Journal of Computing and Information Technology, 18(4), 369-375.

Kosacoff, B. (editor) (2009), La Argentina ante la nueva internacionalización de la producción: crisis y oportunidades, CEPAL, Chile.

Koschatzky, K. (2002), "Fundamentos de la economía de redes. Especial enfoque a la innovación”, Economía Industrial, 346, p. $15-26$.

Krippendorff, K. (2018), Content analysis: An introduction to its methodology, Sage publications.

Kuemmerle, W. (1999), "The drivers of foreign direct investment into research and development: an empirical investigation", Journal of International Business Studies, 30(1) 1-24.

Kumar, N. (2001), "Determinants of location of overseas R\&D activity of multinational enterprises: the case of US and Japanese corporations", Research Policy, 30(1) 159-174.

Lall, S., \& Narula, R. (2004), "Foreign direct investment and its role in economic development: do we need a new agenda?", The European Journal of Development Research, 16(3) 447-464.

Le Bas, C., \& Sierra, C. (2002), "Location versus home country advantages in R\&D activities: some further results on multinationals' locational strategies", Research Policy, 31(4), 589-609.

Montes-Valencia, N. (2015), "La Industria Química: Importancia y Retos", Lámpsakos, 14, 72-85.

Moran, T., \& Moran, T. (2000), Inversión extranjera directa y desarrollo, Oxford.

Moran, T., Graham, E., \& Blomström, M. (2005), Does foreign direct investment promote development?, Peterson Institute.

Mortimore, M., Vergara, S., \& Katz, J. (2001), La competitividad internacional y el desarrollo nacional: implicancias para la política de Inversión Extranjera Directa (IED) en América Latina, CEPAL, Chile.

Mulyana, M., \& Wasitowati, W. (2021), "The improvement of collaborative networks to increase small and medium enterprises (SMEs) performance", Serbian Journal of Management, 16(1), 213-229.

Ozawa, T. (1992), "Foreign direct investment and economic development, Transnational Corporations", 1(1), 27-54.

Patel, P., \& Pavitt, K. (1991), "Large firms in the production of the world's technology: an important case of "nonglobalisation", Journal of International Business Studies, 22(1), 1-21.

Perkmann, M., \& Walsh, K. (2007), "University-industry relationships and open innovation: Towards a research agenda", International Journal of Management Reviews, 9(4), 259-280.

Perrotta, D., \& Fulquet, G.; Inchauspe, E. (2011), Luces y sombras de la internacionalización de las empresas brasileñas en Sudamérica: ¿integración o interacción, Nueva Sociedad, Buenos Aires; Argentina.

Pietrobelli, C., \& Sverrison, A. (ed.). (2005), Linking local and global economies: The ties that bind, Routledge, London.

Prebisch, R. (1986), "El desarrollo económico de la América Latina y algunos de sus principales problemas", Desarrollo Económico, 26(103), 479-502.

Raposo, N. (2004), "Redes empresariales de oportunidad en la España del siglo XX: el caso de la industria químicofarmacéutica", Historia, 812, 179-188.

Rojo, I. (2001), "Cooperación empresarial y asociacionismo como estrategias de desarrollo de los países más desfavorecidos en un entorno globalizado", Boletín económico de ICE, Información Comercial Española, (2685), 1930.

Rozo, C. (1993), “Internacionalización y competitividad”, Política y Cultura, 2, 307-318. 
Ryu, D., Baek, K. H., \& Yoon, J. (2021), “Open Innovation with Relational Capital, Technological Innovation Capital, and International Performance in SMEs", Sustainability, 13(6), 3418.

Sevilla, B. (2019), Empresas químicas líderes en ventas a nivel mundial, Madrid: Statista.

Link:https://es.statista.com/estadisticas/600781/empresas-quimicas-lideres-de-ventas-a-nivel-mundial/

Schmitz, H. (1999), "Global competition and local cooperation: success and failure in the Sinos Valley, Brazil", World Development, 27(9), 1627-1650.

Sternberg, R. (2000), "Innovation networks and regional development-evidence from the European Regional Innovation Survey (ERIS): theoretical concepts, methodological approach, empirical basis and introduction to the theme issue", European Planning Studies, 8(4), 389-407.

Pérez, A. (2012), "Construcción de redes de transferencia ciencia-industria en el sector de biotecnología en México: Estudio de caso sobre las vinculaciones tecnológicas entre investigadores de CINVESTAV Irapuato y LANGEBIO y empresas del sector agro-biotecnológico", Estudios Sociales, 20(39), 9-38.

Rogerson, C. M. (2019), Revamping Local Economic Development Policy in South Africa in The Geography of South Africa, 253-259, Springer, Cham.

Stumpo, G., Katz, J., \& Alarcón, C. (1996), Encadenamientos, articulaciones y procesos de desarrollo industrial, CEPAL, Chile.

Trigilia, C. (2001), "Social capital and local development", European Journal of Social Theory, 4(4), 427-442.

Von Zedtwitz, M., \& Gassmann, O. (2002), "Market versus technology drive in R\&D internationalization: four different patterns of managing research and development", Research Policy, 31(4), 569-588.

Wei, D., \& Leung, C. (2005), "Development zones, foreign investment, and global city formation in Shanghai", Growth and Change, 36(1), 16-40.

Wright, M., Westhead, P., \& Ucbasaran, D. (2007), “Internationalization of small and medium-sized enterprises (SMEs) and international entrepreneurship: A critique and policy implications", Regional Studies, 41(7), 1013-1030.

Zcan, B. (1995), "Small business networks and local ties in Turkey", Entrepreneurship \& Regional Development, 7(3), 265284. 